DOI: 10.36910/6775-2524-0560-2020-40-04

УДК: 629.7.014

Єршов Владислав Володимирович,аспірант

https://orcid.org/0000-0001-7402-3879

Ізвалов Олексій Володимирович, кандидат тех. наук, доцент

https://orcid.org/0000-0002-4935-7153

Неділько Сергій Миколайович, доктор тех. наук, професор

https://orcid.org/0000-0003-0878-3313

Неділько Віталій Миколайович, кандидат тех. наук, доцент

https://orcid.org/0000-0003-3595-6590

Льотня академія Національного Авіаційного Університету

\title{
КОНЦЕПЦІЯ СИСТЕМАТИЗОВАНОГО УПРАВЛІННЯ ПОЛЬОТОМ БЕЗПІЛОТНИХ ЛІТАЛЬНИХ АПАРАТІВ
}

Єршов В. В., Ізвалов О. В., Неділько С. М. Неділько В. М. Концепція систематизованого управління польотом безпілотних літальних апаратів. Розкрито концепцію систематизованого управління польотом безпілотних літальних апаратів. Визначено спектр оснащення безпілотних літальних апаратів різною технічною апаратурою. Зазначено, що управління польотом безпілотного літального апарату грунтується на формуванні єдиної системи взаємозв'зку всіх параметрів та датчиків. Кожен БПЛА в основі має певні контури управління, на кожен контур надходять параметри, що задаються і параметри з датчиків, встановлених на борту БПЛА, про поточний стан апарата. Схематично наведено контур управління кутовою стабілізацією безпілотного літального апарату. Описано структуру контуру управління орієнтацією безпілотного літального апарату. Контур складається з чотирьох блоків контролюючих крен, тангаж, рискання і висоту. Запропоновано структуру блоку «змішування» управління рухом безпілотного літального апарату, цей блок приймає команди корекції для крену, тангажу, рискання, висоти і «змішує» їх, відправляючи кожну поправку на правильний двигун. Окреслено блок динаміки двигуна безпілотного літального апарату, який обмежує вхідні команди від 0 до 100\% дросельної заслінки, імітує поведінку обриву двигуна при дуже низькому дроселі і найбільш важливо застосовує лінійну залежність до сигналу відсотка дроселя, підкреслено, що вихід блоку - це число оборотів в хвилину для кожного двигуна в будь-який момент часу. Розроблено структурну схему безпілотного літального апарату. Для вирішення завдань систематизованого управління польотом безпілотних літальних апаратів обрана структура та описано обладнання, що входить у кожний рівень. Обгрунтовано аеродинамічний баланс безпілотного літального апарату, принцип його стабілізації полягає у збереженні постійного зчитування показань сенсорів і внесення відповідних змін до швидкості обертання кожного ротора. Управління безпілотним літальним апаратом здійснюється по 4-м осям: рисканню за курсом, крену щодо поздовжньої осі, тангажу, висоті польоту.

Ключові слова: безпілотний літальний апарат, концепція, управління, політ, оператор, контур, динаміка, експлуатація, перешкоди.

Ершов В. В., Извалов А. В., Неделько С. Н., Неделько В. Н. Концепция систематизированного управления полетом беспилотных летательных аппаратов. Раскрыто концепцию систематизированного управления полетом беспилотных летательных аппаратов. Определены спектр оборудования беспилотных летательных аппаратов различной технической аппаратурой. Указано, что управление полетом беспилотного летательного аппарата основывается на формировании единой системы взаемозвьзку всех параметров и датчиков. Каждый БПЛА в основе имеет определенные контуры управления, на каждый контур поступают параметры, задаваемые и параметры с датчиков, установленных на борту БПЛА, о текущем состоянии аппарата. Схематично приведены контур управления угловой стабилизацией беспилотного летательного аппарата. Описана структура контура управления ориентацией беспилотного летательного аппарата. Контур состоит из четырех блоков контролирующих крен, тангаж, рыскание и высоту. Предложена структура блока «смешивания» управления движением беспилотного летательного аппарата, этот блок принимает команды коррекции для крена, тангажа, рыскания, высоты и «смешивает» их, отправляя каждую поправку на правильный двигатель. Определены блок динамики двигателя беспилотного летательного аппарата, который ограничивает входные команды от 0 до $100 \%$ дроссельной заслонки, имитирует поведение обрыва двигателя при очень низком дроссели и наиболее важно применяет линейную зависимость от сигнала процента дросселя, подчеркнуто, что выход блока - это число оборотов в минуту для каждого двигателя в любой момент времени. Разработана структурная схема беспилотного летательного аппарата. Для решения задач систематизированного управления полетом беспилотных летательных аппаратов выбрана структура и описаны оборудования, входящего в каждый уровень. Обоснованно аэродинамический баланс беспилотного летательного аппарата, принцип его стабилизации заключается в сохранении постоянного считывания показаний сенсоров и внесения соответствующих изменений в скорости вращения каждого ротора. Управление беспилотным летательным аппаратом осуществляется по 4-м осям: рысканию по курсу, крену относительно продольной оси, тангажу, высоте полета.

Ключевые слова: беспилотный летательный аппарат, концепция, управления, полет, оператор, контур, динамика, эксплуатация, препятствия.

Yershov V. V., Izvalov O. V., Nedilko S. M., Nedilko V. M. Concept of systematized flight control of unmanned aircraft

The concept of systematic flight control of unmanned aerial vehicles is revealed. The range of equipment of unmanned aerial vehicles with various technical equipment is determined. It is noted that the flight control of an unmanned aerial vehicle is based on the formation of a single system of interconnection of all parameters and sensors. Each UAV basically has certain control circuits, each circuit receives the parameters set and the parameters from the sensors installed on board the UAV, the current state of the device. The control circuit of the angular stabilization of the unmanned aerial vehicle is schematically shown. The structure of the control circuit (C) Єршов В. В., Ізвалов О. В., Неділько С. М. Неділько В. М. 
of the orientation of the unmanned aerial vehicle is described. The contour consists of four blocks controlling roll, pitch, yaw and height. The structure of the unmanned aerial vehicle motion control "mixing" unit is proposed, this unit receives correction commands for roll, pitch, yaw, height and "mixes" them, sending each correction to the correct engine. The engine dynamics of an unmanned aerial vehicle engine is outlined, which limits the input commands from 0 to $100 \%$ of the throttle valve, simulates the engine break behavior at a very low throttle and most importantly applies a linear relationship to the throttle percentage signal. for each engine at any time. The structural scheme of the unmanned aerial vehicle is developed. To solve the problems of systematic flight control of unmanned aerial vehicles, the structure is selected and the equipment included in each level is described. The aerodynamic balance of the unmanned aerial vehicle is substantiated, the principle of its stabilization is to maintain a constant reading of the sen sor readings and make appropriate changes to the speed of each rotor. The control of the unmanned aerial vehicle is carried out on 4 axes: scrolling on the course, roll relative to the longitudinal axis, pitch, altitude.

Key words: unmanned aerial vehicle, concept, control, flight, operator, contour, dynamics, operation, obstacles.

Вступ та проблематика дослідження. Протягом останнього десятиліття на території України більшої актуальності набуває застосування безпілотних літальних апаратів (БПЛА) [1]. БПЛА покликані вирішувати широкий спектр завдань цивільного застосування. Основними перевагами використання БПЛА є універсальність, гнучкість, відносно невеликі експлуатаційні витрати i виключення людського фактору при виконанні поставленого завдання [2]. Аналіз завдань, які виконуються за допомогою систем, що складаються з одиночних БПЛА, дозволяє зробити висновок про те, що застосування систем БПЛА $є$ найбільш ефективним підходом у вирішення різних завдань у всіх сферах життя сучасної людини.

Основною перевагою БПЛА $є$ повне або часткове виключення людського фактора, що дозволяє мінімізувати ризик втрати людських ресурсів при виконанні поставленого завдання і виключити можливість загрози життю людини. До інших переваг використання безпілотного літального апарату можна віднести: зменшення вартості виконання робіт і меншу кількість регламентних операцій, в порівнянні 3 пілотованою технікою, відсутність необхідності у висококваліфікованій технічній допомозі при обслуговуванні.

Залежно від призначення і області застосування, безпілотний літальний апарат оснащується різною технічною апаратурою, що включає в себе різноманітні датчики, різнодіапазонні камери, іта інші засоби фіксування, отримання і передачі необхідної інформації. Для позначення цієї сукупності (БПЛА і його приладового оснащення), введено термін безпілотна авіаційна система (БАС). БАС так само включає в себе бортовий комплекс управління, корисне навантаження, тобто технічне оснащення, і наземний комплекс управління.

Аналіз останніх досліджень і публікацій. В умовах сьогодення, концепція систематизованого управління польотом безпілотних літальних апаратів розглянута у багатьох наукових працях.

Б.П. Книш [1] наводить класифікацію відомих видів безпілотних літальних апаратів. В роботі розглянуто основні види безпілотних літальних апаратів та ознаки, по яких вони класифікуються, а саме - за масштабом завдань, що вирішуються, за масою, за тривалістю польоту, за практичною стелею польоту, за типом літального апарату, за базуванням, за використанням, за типом системи керування, за правилами польоту, за типом крила, за напрямком, за типом, за паливною системою, за типом паливного бака, за кількістю використань, за радіусом дії.

С. О. Бондар, О. В. Кожохіна, В. О. Боровик, Я. М. Ліндер, М. В. Коршунов [2] дослідили наявні комплекси групової безпілотної авіації, основні задачі їх застосування та, грунтуючись на цьому, вивели їх основні переваги та недоліки. Для компенсації найбільш значущих 3 них, провели порівняльний аналіз алгоритмів керування групою безпілотних літальних апаратів, як наявних, так $\mathrm{i}$ перспективних.

Ю. Г. Даник, О. В. Манько, В. В. Павлюк [3] розробили алгоритм, який забезпечує встановлення факту належності прийнятого радіовипромінювання до класу радіосигналів систем дистанційного керування безпілотними літальними апаратами 3 імпульсно-позиційною та імпульсно-кодовою модуляціями. Алгоритм базується на послідовних перевірках енергетичної, модуляційної та структурної ознак сигналу, передбачає можливість автоматичного виявлення сигналу та супроводження його за частотою.

В.І. Гриценко, О.С. Волков, М.М. Комар, Ю.П. Богачук [4], дослідили головні аспекти оптимізації системи управління легкого безпілотного літального апарату за частотним критерієм, математично обгрунтував вибір напрямку руху та обхід перешкод.

Систему інформаційно-вимірювальну та управляючу малорозмірного безпілотного літального апарату підвищеної точності, обгрунтував схемами та розрахунком В.П. Бабенко [5].

Щодо автоматичного управління системою навігації безпілотного літального апарату, варто відмітити роботи: І. О. Кашаєва, О. А. Усачова, С. М. Новічонка, В. М. Петрова [6], О. В. Ярового [7], О. А. Мясіщева, В.В. Швеця [8], та ін.. Автори детально описують можливість застосування () Єршов В. В., Ізвалов О. В., Неділько С. М. Неділько В. М. 
автоматичного управління системою навігації БПЛА в умовах перешкод та механізми формування траєкторії польоту.

Також варто відмітити роботи так вчених як: Williams P., та Crump M [9] та Tang D., Li F., Shen N., i Guo S. [10].

Однак, питання обгрунтування концепції систематизованого управління польотом безпілотних літальних апаратів розглянуто не повною мірою та потребує додаткового дослідження.

Мета та задачі статті. Метою даного дослідження виступає розробка концепції систематизованого управління польотом безпілотних літальних апаратів. У рамках статті потрібно виконати наступні задачі:

- дослідити контур управління кутовою стабілізацією безпілотного літального апарату;

- розкрити сутність систематизованого управління польотом безпілотних літальних апаратів з наведенням блоку динаміки двигуна БПЛА;

- навести структурну схему управління польотом безпілотних літальних апаратів 3 відокремленням кожного блоку системи.

Виклад основного матеріалу. Управління польотом безпілотного літального апарату грунтується на формуванні єдиної системи взаємозв'зку всіх параметрів та датчиків. За допомогою пульта управління задаються початкові координати літального апарату g. На кожен контур надходять параметри, що задаються і параметри $з$ датчиків, встановлених на борту БПЛА, про поточний стан апарата. У контурах формуються регулюючі дії, що передаються на мікшер, який в свою чергу подає керуючу напругу на кожен з двигунів.

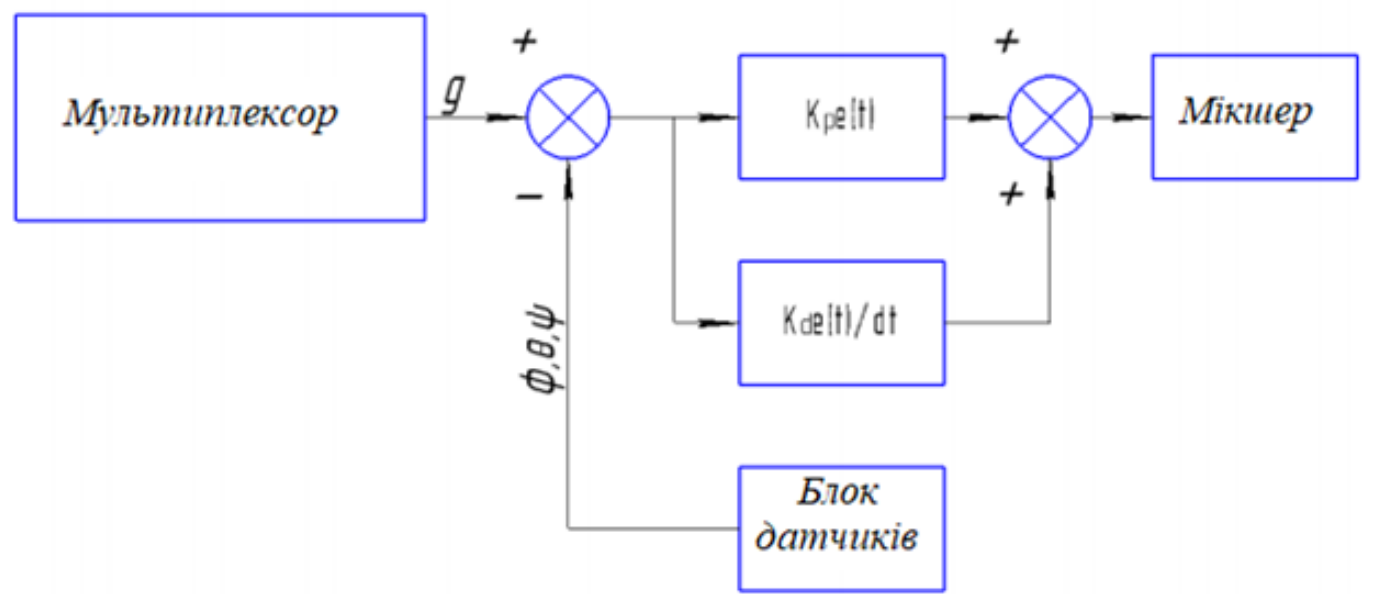

Рис. 1. Контур управління кутовою стабілізацією безпілотного літального апарату [10]

Після того, як блоком датчиків були отримані кути крену, тангажу і рискання, необхідно застосувати поправку до потужностей двигунів, для усунення можливого відхилення. Для досягнення цієї мети зазвичай застосовується ПІД або ПД регулятор.

У даній системі застосовується ПД регулятор. ПД (пропорціонально диференціальний) регулятор - алгоритм, який на основі відхилення від величини, в якій необхідно стабілізуватися, видає поправку на відповідні мотори.

Будемо вважати відхилення від необхідної величини в момент часу t рівним $e(t)$, тоді формула, наведена нижче, показує необхідну поправку. $\mathrm{K}_{\mathrm{P}}, \mathrm{K}_{\mathrm{D}}$ - пропорційний $\mathrm{i}$ диференційний коефіцієнти відповідно. У разі ПД регулятора інерціальна компонента дорівнює нулю. Динамічна помилка е $(\mathrm{t})=$ 0 .

$$
u(t)=K_{P} e(t)+K_{D} \frac{d e(t)}{d t} .
$$




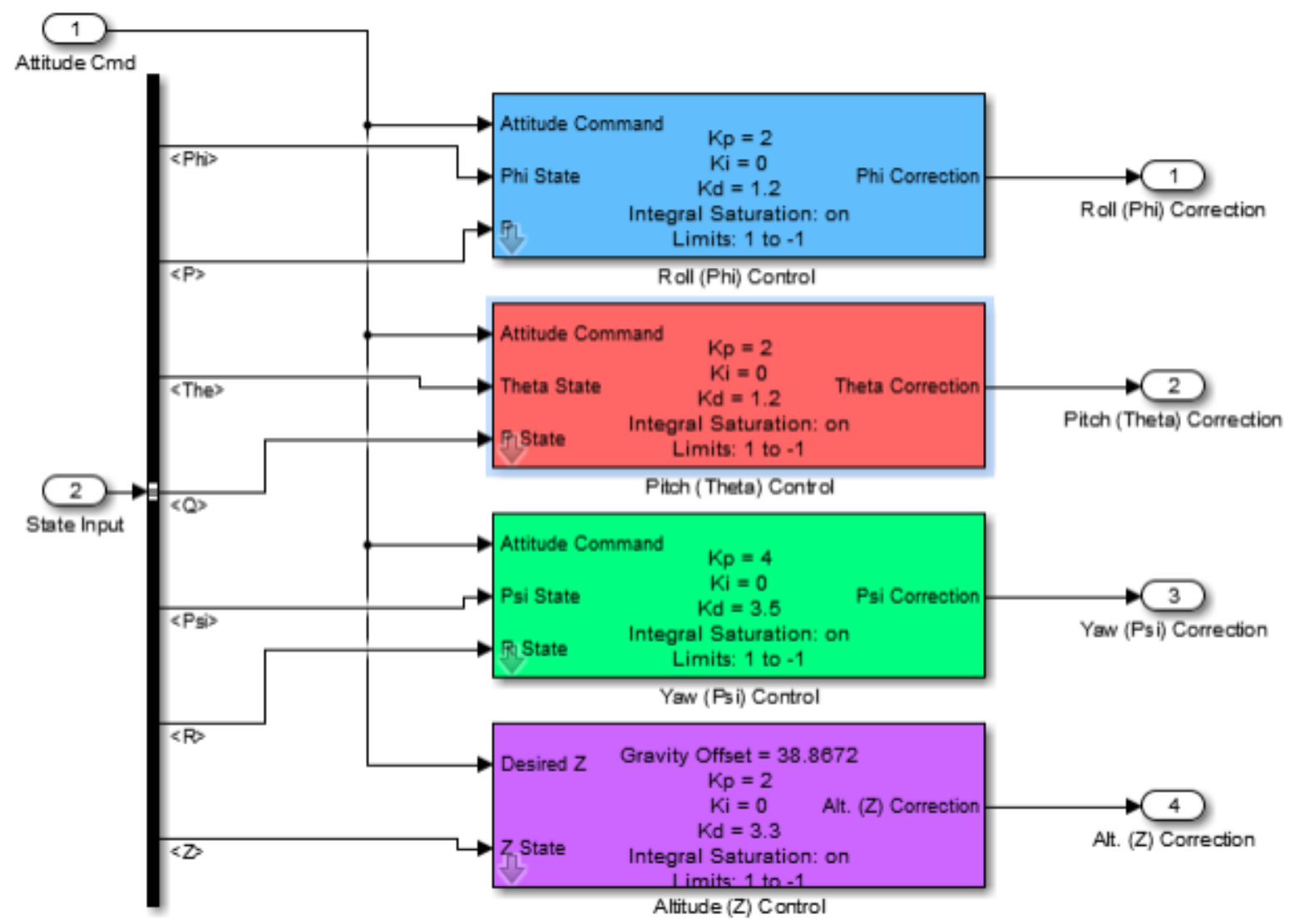

Рис. 2. Структура контуру управління орієнтацією безпілотного літального апарату [10]

Розглянемо блок управління орієнтацією безпілотного літального апарату в програмному забезпеченні Matlab Simulink. Контур складається з чотирьох блоків контролюючих крен, тангаж, рискання і висоту. Текст на передній частині цих блоків можна змінювати, щоб відобразити значення коефіцієнтів посилення ПД регулятора.

Цей блок (рисунок 3) приймає команди корекції для крену, тангажу, рискання, висоти i «змішує» їх, відправляючи кожну поправку на правильний двигун. На передній панелі представлена завантажена конфігурація «+». Призначення механізму перемикання полягає в тому, щоб правильно керувати транспортними засобами «Х» конфігурації і «+»», Не використовуючи інший блок.

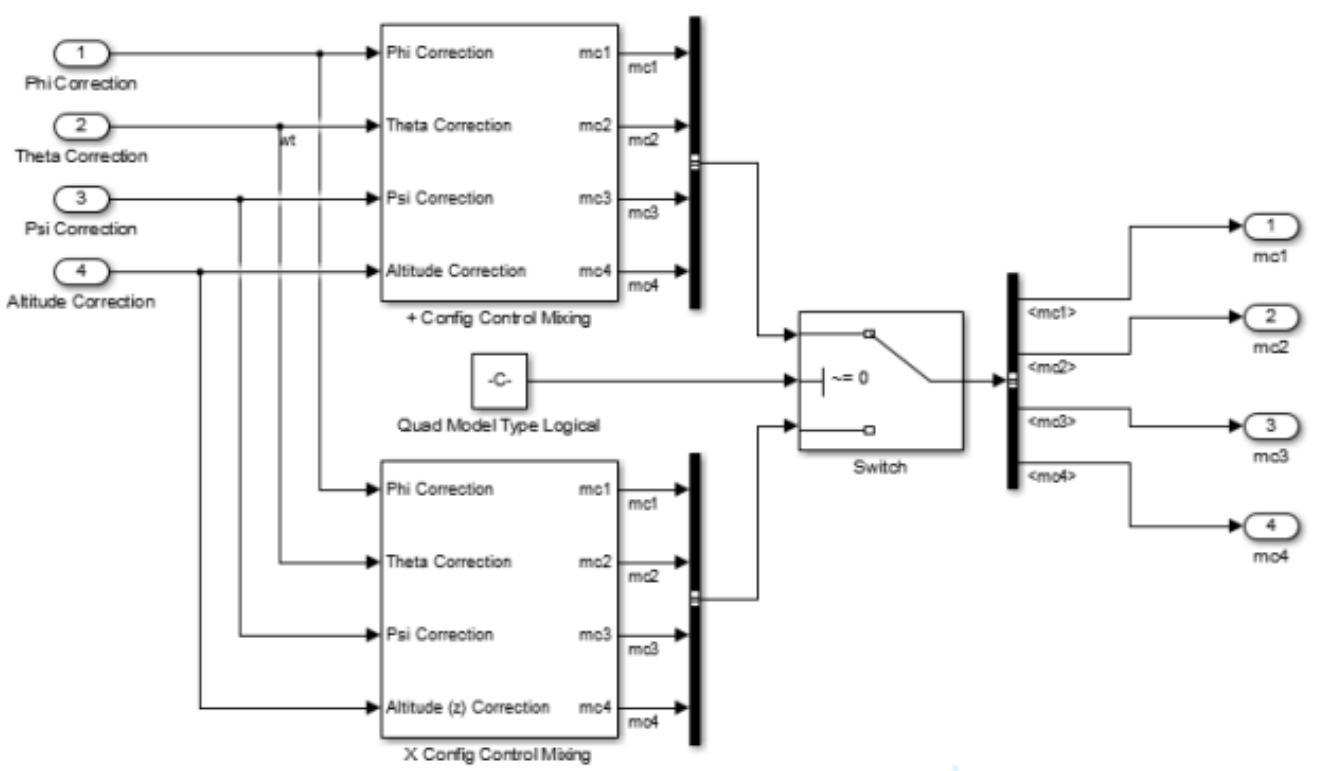

Рис. 3. Структура блоку «змішування» управління рухом безпілотного літального апарату [10] 
Рівняння записуються поруч з кожним виходом для довідки. Слід зазначити, що ці вихідні сигнали виражені у відсотках дроселя.

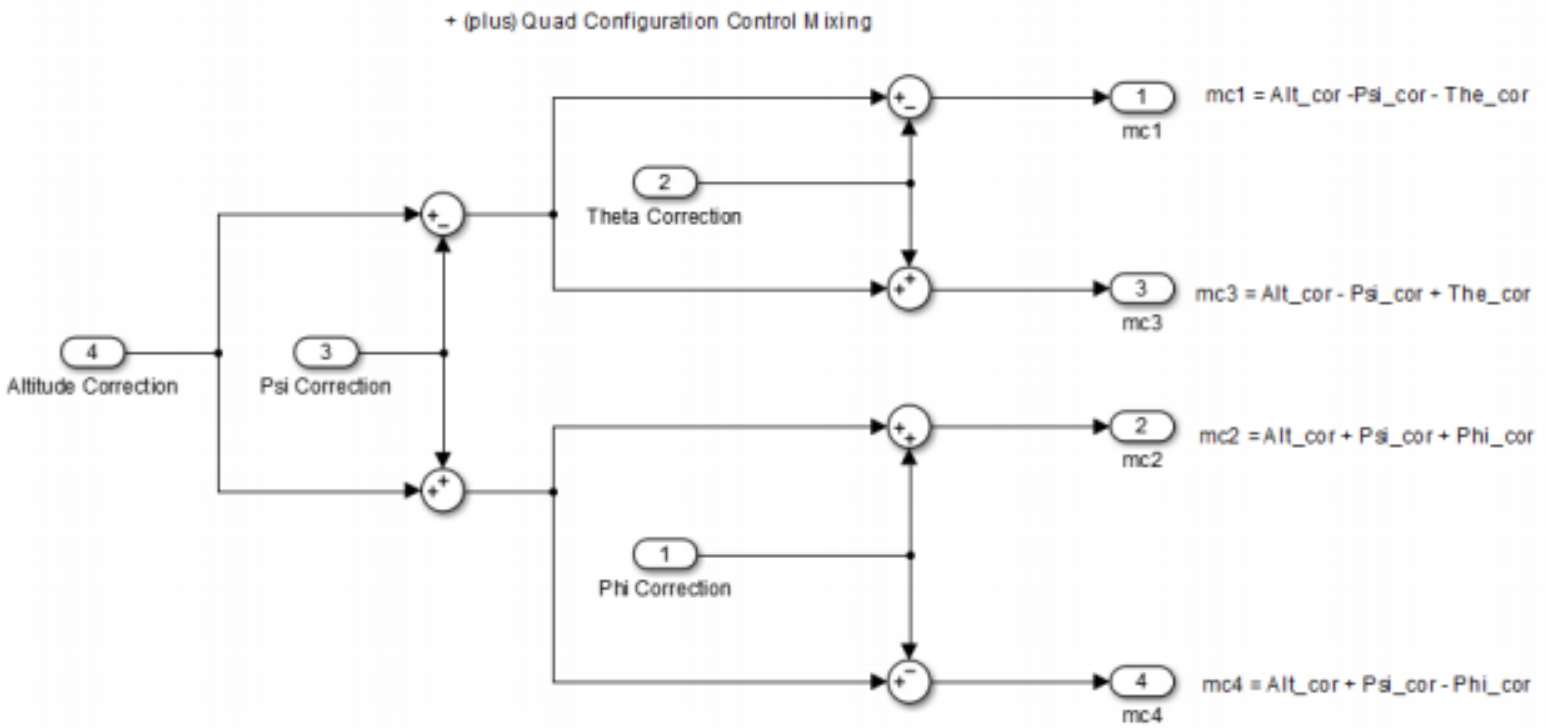

Рис. 4. Управління «+» конфігурацією [10]

Даний факт дозволяє налаштовувати контролер і очікувати такої ж продуктивності від модельованого безпілотного літального апарату для даної системи управління великою кількістю коефіцієнтів посилення, які можна отримати від реальної системи управління.

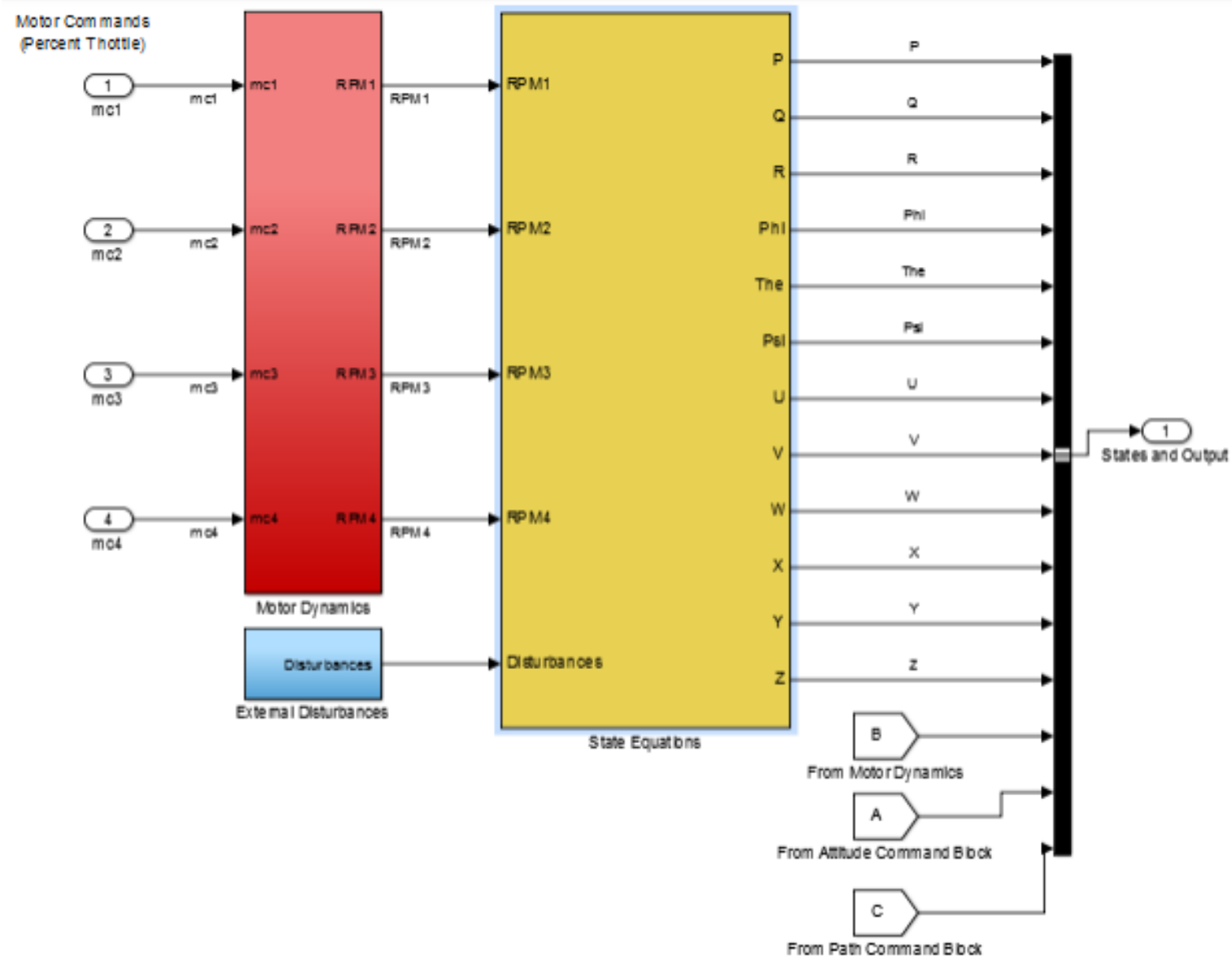

Рис. 5. Блок динаміки двигуна безпілотного літального апарату [10] 
Блок динаміки двигуна обмежує вхідні команди від 0 до 100\% дросельної заслінки (що є максимально можливим діапазоном сигналів управління дросельною заслінкою), імітує поведінку обриву двигуна при дуже низькому дроселі і найбільш важливо застосовує лінійну залежність $C R$ i b до сигналу відсотка дроселя. Вихід блоку - це число оборотів в хвилину для кожного двигуна в будьякий момент часу [10].

У блоці State Equations моделюються основні рівняння, що описують динамічну поведінку безпілотного літального апарату.

Аеродинамічний баланс безпілотного літального апарату зберігається постійним зчитуванням показань сенсорів і внесення відповідних змін до швидкості обертання кожного ротора. 3 огляду на, що ручне управління чотирма окремими двигунами вкрай утруднено, за підтримку балансу БПЛА відповідає відповідна автоматична контрольна система. Управління БПЛА здійснюється по 4-м осям: рисканню за курсом, крену щодо поздовжньої осі, тангажу, висоті польоту. Структура системи контролю і регулювання польоту безпілотного літального апарату представлена на рисунку 6.

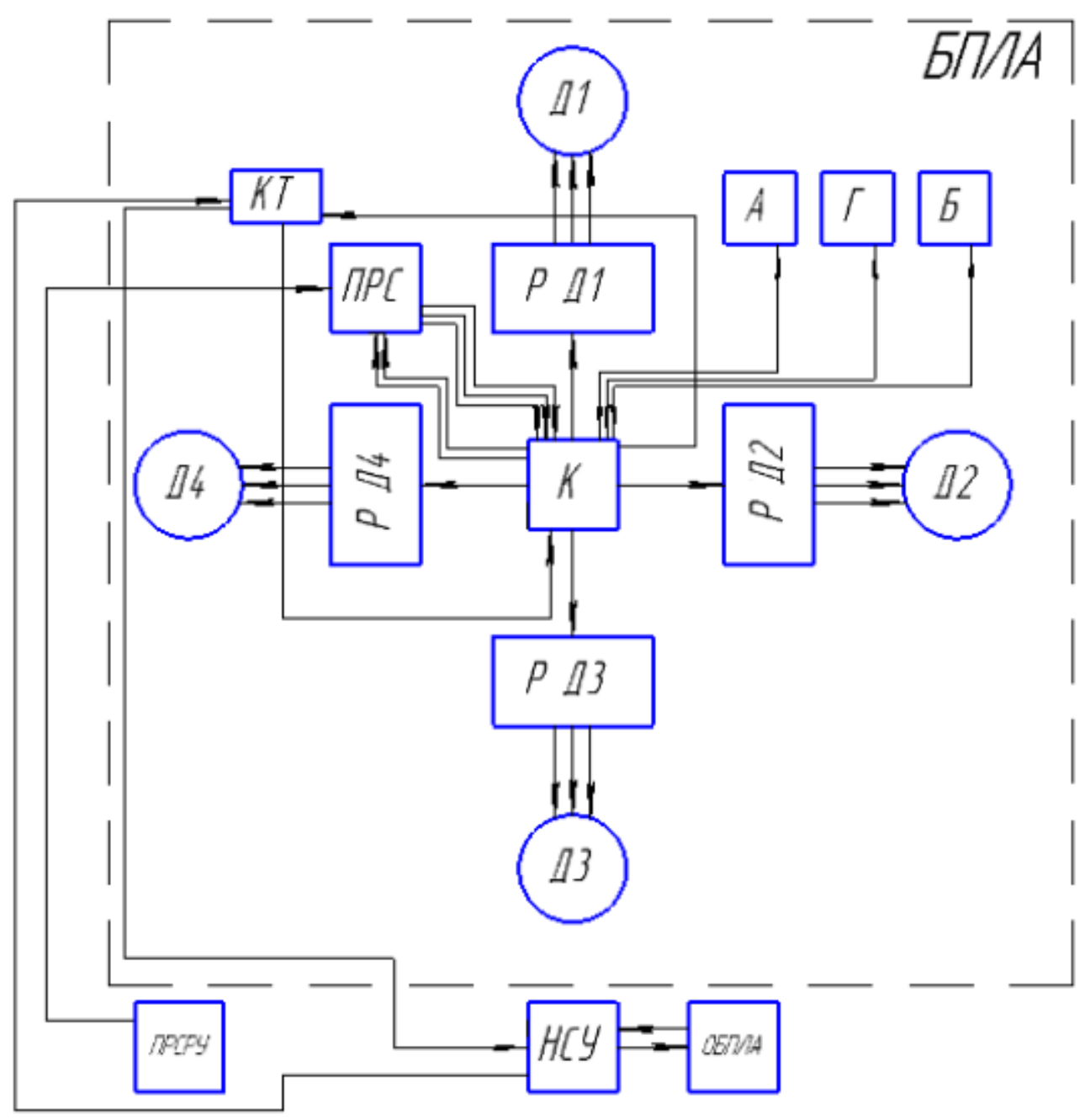

Рис. 6. Структурна схема БПЛА [9]

Для вирішення завдань систематизованого управління польотом безпілотних літальних апаратів обрана структура, яка включає в себе наступне обладнання:

1) нижній рівень:

- інерційні датчики;

- первинні засоби вимірювання;

- приймач і передавач радіосигналу;

- регулятори швидкості обертання ротора двигунів;

2) середній рівень:

- польотний контролер;

3) верхній рівень:

() Єршов В. В., Ізвалов О. В., Неділько С. М. Неділько В. М. 
- робоче місце оператора безпілотного літального апарату.

Таблиия 1

Розшифровка позначень на структурній схемі БПЛА

\begin{tabular}{|l|l|l|}
\hline$№$ & Позначення & Розшифрування \\
\hline 1 & Р Д1 & Регулятор швидкості обертання ротора першого двигуна \\
\hline 2 & Р Д2 & Регулятор швидкості обертання ротора другого двигуна \\
\hline 3 & Р Д3 & Регулятор швидкості обертання ротора третього двигуна \\
\hline 4 & Р Д4 & $\begin{array}{l}\text { Регулятор швидкості обертання ротора четвертого } \\
\text { двигуна }\end{array}$ \\
\hline 5 & ПРС & Приймач радіосигналу \\
\hline 6 & ПРСРУ & Передавач радіосигналу, ручне управління \\
\hline 7 & НСУ & Наземна станція управління \\
\hline 8 & ОБПЛА & Оператор безпілотного літального апарату \\
\hline 9 & БПЛА & Безпілотний літальний апарат \\
\hline 10 & КТ & Канал телеметрії \\
\hline 11 & А & Акселерометр \\
\hline 12 & Г & Гіроскоп \\
\hline 13 & Б & Барометр \\
\hline
\end{tabular}

Висновки та перспективи подалыших досліджень. Систематизоване управління польотом безпілотних літальних апаратів $є$ головним напрямком реалізації ефективного та безпечного руху БПЛА в умовах експлуатації. Системне налаштування всіх контурів дозволяє здійснювати управління рухом БПЛА, як в стабільному стані, так і за умови виникнення перешкод.

Список бібліографічного опису

1. Книш, Б. П., Кулик, Я. А., \& Барабан, М. В. (2018). Класифікація безпілотних літальних апаратів та їх використання для доставки товарів. Вісник Хмельнищького національного університету. Технічні науки, 3, 246-252.

2. Бондар, С. О., Кожохіна, О. В., Боровик, В. О., Ліндер, Я. М., \& Коршунов, М. В. (2018). Перспективи та особливості групового використання безпілотних літальних апаратів. Управляющие системы и машины, 5, 25-37.

3. Даник, Ю. Г., Манько, О. В., \& Павлюк, В. В. (2013). Алгоритм виявлення радіосигналів систем дистанційного керування безпілотними літальними апаратами. Проблеми створення, випробування, застосування та експлуатації складних інформаційних систем, (7), 5-13.

4. Гриценко, В. І., Волков, О. С., Комар, М. М., \& Богачук, Ю. П. (2018). Інтелектуалізація сучасних систем автоматичного керування безпілотними літальними апаратами. Кибернетика и вычислительная техника, 1 (191), 45-59.

5. Бабенко В.П. Формування траси польоту бпла під час планування розвідувальних операцій. Інформаційні технології: наука, техніка, технологія, освіта, здоров'я: тези доповідей XXVII міжнародної науково-практичної конференції МicroCAD2019 (м. Харків, 15-17 травня 2019 р.: у 5 ч. Ч. V. / за ред. проф. Сокола Є.І. Харків: НТУ “ХПІ”, 15-16.

6. Кашаєв, І. О., Усачова, О. А., Новічонок, С. М., \& Петров, В. М. (2019). Застосування безпілотних літальних апаратів для вирішення задач моніторингу об' єктів аеродромної інфраструктури. Збірник наукових праць Харківського національного університету Повітряних Сил, (2), 48-58.

7. Яровий, О. В. (2018). Вибір оптимальних моделей безпілотних літальних апаратів та систем управління для виконання задач щодо моніторингу наземних об'єктів. Молодий вчений, (5 (1)), 190-196.

8. Мясіщев, О. А., \& Швець, В. В. (2018). Режими польоту контролерів польоту apm 2.6 i pixhawk БПЛА. Bicник Хмельницьккого національного університету. Технічні науки. Хмельницьк, 1 (257), 78-82.

9. Williams, P., \& Crump, M. (2012). All-source navigation for enhancing UAV operations in GPS-denied environments. In Proceedings of the 28th International Congress of the Aeronautical Sciences. Brisbane, September 2012.

10. Tang, D., Li, F., Shen, N., \& Guo, S. (2011, August). UAV attitude and position estimation for vision-based landing. In Proceedings of 2011 International Conference on Electronic \& Mechanical Engineering and Information Technology (Vol. 9, pp. 4446-4450). IEEE.

\section{References}

1. Knish, B. P., Kulik, J. A., \& Baraban, M. V. (2018). Classification of unmanned aerial vehicles and their use for delivery of goods. Bulletin of Khmelnytsky National University. Technical Sciences, 3, 246-252.

2. Bondar, S. O., Kozhokhina, O. V., Borovik, V. O., Linder, J. M., \& Korshunov, M. V. (2018). Prospects and features of group use of unmanned aerial vehicles. Control systems and machines, 5, 25-37.

3. Danik, Yu. G., Manko, OV, \& Pavlyuk, VV (2013). Algorithm for detecting radio signals of remote control systems for unmanned aerial vehicles. Problems of creation, testing, application and operation of complex information systems, (7), 5-13.

4. Gritsenko, V. I., Volkov, O. C., Komar, M. M., \& Bogachuk, Yu. P. (2018). Intellectualization of modern systems of automatic keruvannya by non-portable devices. Cybernetics and Computing, 1 (191), 45-59.

5. Babenko V.P. Formation of the route for the flight of the UAV before an hour of planning the development operations. Information technologies: science, technology, technology, education, health: theses of the XXVII international scientific and practical conference MicroCAD-2019 (Kharkiv m., 15-17 May 2019: at 5 o'clock, Part V. / Ed. Prof. Sokola V.I. Kharkiv: NTU "KhPI", $15-16$.

(с) Сршов В. В., Ізвалов О. В., Неділько С. М. Неділько В. М. 
6. Kashaev, I. O., Usachova, O. A., Novichonok, S. M., \& Petrov, V. M. (2019). The stagnation of non-portable devices for the transmission of tasks to the monitoring of aerodrome infrastructure. Collection of Science Practitioners of Kharkiv National University of Powers, (2), 48-58.

7. Yarovy, O. V. (2018). Vibir of the optimal models of non-powered lithal devices and control systems for monitoring tasks for monitoring ground-based facilities. Molodiy Vchenii, (5 (1)), 190-196.

8. Myasishchev, O. A., \& Shvets, V. V. (2018). Moderate controllers for apm 2.6 and pixhawk UAVs. Visnik of Khmelnytsky National University. Technical sciences. Khmelnitsk, 1 (257), 78-82.

9. Williams, P., \& Crump, M. (2012). All-source navigation for enhancing UAV operations in GPS-denied environments. In Proceedings of the 28th International Congress of the Aeronautical Sciences. Brisbane, September 2012.

10. Tang, D., Li, F., Shen, N., \& Guo, S. (2011, August). UAV attitude and position estimation for vision-based landing. In Proceedings of 2011 International Conference on Electronic \& Mechanical Engineering and Information Technology (Vol. 9, pp. 4446-4450). IEEE. 